\title{
A Study of Students' Reading Habits In MTS Al-Hidayah Tapung Hilir Sub- Disrict Kampar Regency of Riau
}

\author{
Candra Kirana \\ Akademi Kebidanan Helvetia Pekanbaru \\ Ckirana17@gmail.com
}

\begin{abstract}
This study focus on investigated the English reading habits of students' MTS Alhidayah Tapung Hilir Sub-District Kampar Regency of Riau 2016. The data were collected through a questionnaire survey and interview validation. The questionnaires were distributed to 50 students. Based on the statistical analysis of the data, it is concluded little students like reading English that consists of 15 respondents $(30 \%)$. The other side, the most common of students' activity were doing in free time watching TV that consists of 25 respondents' (50\%). Then, reading habit is not became our culture in young generation which this indicator the most common of student's seldom reading English book that consists of 30 respondents' $(60 \%)$. In addition, the most common of students' activity were read for doing assignments that consists of 25 respondents' (50\%). The last factor about students' underestimates, the most common have same data of students' underestimate were English is not guaranteed support my carrier in future that consists of 15 respondents' (30\%) and the students' underestimate were English is not priority because it doesn't use for daily communication that consists of 15 respondents' (30\%). So, it needs the culture of reading habit especially in English by promoting English club. The teacher and the parent collaboration to supporting awareness of reading habit become a duty.
\end{abstract}

Keywords: Reading, Students' Habits

\section{INTRODUCTION}

Reading is an activity that is full of benefits and very important in our lives. According JJ Wong in Articles (2013) through reading that exposes to new things, new information, new ways to solve a problem, and new ways to achieve one thing. In addition, he stated begin how to build self-confidence, how to make plan better before taking action, how to memorize things better and more.
All of these self-improvements start from the reading; through reading, you create a structured path towards a better understanding and better actions to take in the future.

Reading skill became important in the education field. It is also something crucial and indispensable for the students because the success of their study depends on the greater part of their comprehension to read. If their reading 
skill is poor, they are very likely to fail in their study or at least they will have difficulty in making progress. In other word, if they have a good comprehend in reading, they will have a better chance to succeed in their study. However, according to Syaveny, N. (2017). reading comprehensively by mastering the indicators of reading comprehension that have been discussed is difficult to do by the students in learning English as foreign language. The expectation of teaching English curriculum asks the teacher to do the better effort in teaching English. It is the reason of the teacher to apply kinds of approaches, methods, techniques and strategies in teaching English. it cannot solve the problem and continue to be sustainable which is often applied various methods and approaches in teaching strategy teaching English but still the ability of students in English still remain weak and inadequate with existing standard curriculum. this problem has become the object of some research where it found several factors that greatly affect the student's ability in English language such as: the standard of final achievement in the curriculum requires students to only master the technique in grammar, this we can see from the test that the students are only required to answer the question with the objective form that very rarely found in orally or communicate test in English.

Based on the phenomenon about that found various surveys indicate very low rates of reading habit in Indonesia. Reading habit of Indonesian people can be said is generally still low, especially when compared with other countries, other countries in Asia, like the country Japan, Singapore, even with our near neighboring countries Malaysia though, we still lose. Based on data United Nations Development Program (UNDP) in 2014 reported that Human Development Index (HDI) Indonesia is ranked 110th from 187 countries (www.hdr.undp.org). In the 2016 Human Development report, Indonesia's Human Development Index (IPM) in 2015 is ranked 113; it has down from 110th position in 2014. One of big factor caused that low of reading interest in Indonesia which based on the study of Most Littered Nation in the World 2016 reading interest in Indonesia ranked 60 from 61 countries.

Joko D. Muktiono (2013) said that Indonesian are not became society book reader which this condition we were different with the other country. It has done reading as routinely activities to improving their knowledge and information. However, English subject is taught from elementary school that for 6 years. The others, it is taught from in pre elementary schools. It is continuously thought in junior high school and senior high school. As we know that EFL were thought in Indonesia generally for 13 years that still unsuccessful in create the students' good in reading. As we know, school is a place to building scientist societies that become duties in improving their awareness about reading habit. The students have duties to 
following information as in progress of century.

Bashir and Mattoo (2012) said that "Reading habit are well-planned and deliberate pattern of study which has attained a form of consistency on the part of students toward understanding academic subjects and passing at examination. Reading habits determine the academic achievements of students to a great extent. Both reading and academic achievement are interrelated and dependent on each other."

Regarding the importance of reading, it is essential that students who learn English as their foreign language (EFL) that establish of good reading achievement because they have involved i greatly benefit from reading habits (Erna, 2012; Day, 2002; Atwell (2006). Verplanken and Orbell (2003) said that Reading habit is considered an important construct in reading research as it serves as a significant predictor of good proficiency in English. In addition According to Gardner (2012) Reading habit would help the learner obtaining and gaining a meaningful knowledge and good academic performance in school.

This study discusses about reading habit of English for students' Senior High Schools at Tapung Hilir subdistrict in Kampar regency Riau.

\section{METHOD}

Based on face of problem, this research used survey design. Creswell, J. W. (2015) said that survey research became essential to giving general description of characteristic from the population. It used to collecting the information from students about theirs' reading habit. This study was collecting data by distributed questionnaires to 50 students from Junior high schools at MTS Al-hidayah Tapung Hilir Subdisrict Kampar Regency. The question consists of 5 with linkers scale to asking about respondents' opinion on their habit in English reading. This research also have interview to validation about their potential in English reading skill.

\section{FINDING AND DISCUSSION}

The reading habits among the students' senior high schools Senior High Schools at Tapung Hilir subdistrict in Kampar regency Riau had been surveyed through the seven indicators of reading habits. The first finding results of study about students' level of like or dislike on reading English text.

Table 1. The Level Students' Like on Reading English Text.

\begin{tabular}{ccc}
\hline $\begin{array}{c}\text { The } \\
\text { Level } \\
\text { Students } \\
\text { Like on } \\
\text { Reading } \\
\text { English } \\
\text { Text. }\end{array}$ & $\begin{array}{c}\text { Amount of } \\
\text { Respondents }\end{array}$ & $\begin{array}{c}\text { Percentage } \\
(\%)\end{array}$ \\
\hline $\begin{array}{c}\text { Very } \\
\text { Like }\end{array}$ & & \\
Like & 5 & 10 \\
\hline
\end{tabular}




\begin{tabular}{ccc}
\hline $\begin{array}{c}\text { Between } \\
\text { like or } \\
\text { dislike }\end{array}$ & 20 & 40 \\
Dislike & 10 & 20 \\
Very & - & - \\
Dislike & & \\
\hline
\end{tabular}

Based on table 1 the most common of level students' like on reading English text is between like or dislike that consist of 20 respondents $(40 \%)$. It was followed by students' like that consists of 15 respondents (30\%). Moreover, student's very like on reading English text that consists of 5 respondents $(10 \%)$ and the others respondents is dislike on reading English text that consists of 10 respondents $(20 \%)$.

The respondents' reason why the most of them answer between like or dislike because reading English text is difficult to get understand the text. The others, they claim there is less supporting references of book and facilities. Meanwhile, the other students' like reading English text because they got some information and also convey to improving theirs' knowledge.

The related studies, students' reading habit activity that convey how often they read in their daily lives, especially reading English books.
Table 2. How often students' reading English text?

\begin{tabular}{ccc}
\hline $\begin{array}{c}\text { The } \\
\text { Students, } \\
\text { reading } \\
\text { habit on } \\
\text { English } \\
\text { Text. }\end{array}$ & $\begin{array}{c}\text { Amount of } \\
\text { Respondents }\end{array}$ & $\begin{array}{c}\text { Percentage } \\
(\%)\end{array}$ \\
\hline $\begin{array}{c}\text { Very } \\
\text { Often }\end{array}$ & - & \\
Often & 5 & - \\
sometime & 15 & 10 \\
Seldom & 30 & 30 \\
Never & - & 60 \\
\hline
\end{tabular}

Based on table 2, the most common of student's seldom reading English book that consists of 30 respondents' $(60 \%)$. Consisting of $15(30 \%)$, the respondents' sometime reading English books. The other side, the respondents' often reading English book just consists of 5 students (10\%).

The students' said that reading English book just for doing homework of assignment. The others factor about learning subject to much in a day, they are fed 6-7 different lessons that is very tiring. So, they have to divide time to doing each subject which rottenly rise-up boring and stress.

More intensively, this research needs to find students' habitual these subjects provide to analyze students' activity in free time. This subject will give information about the tendency of students' waste the time for useful or unuseful activity. 
Table 3. The Students' Activity in free time

\begin{tabular}{ccc}
\hline \multicolumn{3}{c}{$\begin{array}{c}\text { The Students' Activity } \\
\text { Amount of Respondents } \\
\text { Percentage (\%) }\end{array}$} \\
\hline $\begin{array}{c}\text { Reading } \\
\text { book }\end{array}$ & 5 & 10 \\
Courses & 2 & 4 \\
$\begin{array}{c}\text { Watching } \\
\text { TV }\end{array}$ & 25 & 50 \\
$\begin{array}{c}\text { Playing } \\
\text { Hand } \\
\text { Phone }\end{array}$ & 15 & 30 \\
\hline Hang-out & 8 & 16 \\
\hline
\end{tabular}

Based on table 3, the most common of students' activity were doing in free time watching TV that consists of 25 respondents'(50\%). It was followed students' playing hand phone that consists of 15 respondents $(30 \%)$. Then, the students' go hang-out that consists of 8 respondents (16\%) and students' courses that consists of 2 respondents (4\%).

The most of students' answer watching TV and play hands phone because they replied to relieve boredom and get entertained. It caused the government have apply full day school.

More comprehensively, this data gave the information to know about students' orientation in reading English. Orientation need to describing the students' motivation why they study English? And desire of intention of the students.
Table. 4 Students' Orientation of study English

\begin{tabular}{|c|c|c|}
\hline $\begin{array}{c}\text { The } \\
\text { Students' } \\
\text { Activity }\end{array}$ & $\begin{array}{c}\text { Amount of } \\
\text { Responden } \\
\text { ts }\end{array}$ & $\begin{array}{c}\text { Percenta } \\
\text { ge }(\%)\end{array}$ \\
\hline $\begin{array}{l}\text { I read } \\
\text { English to } \\
\text { improve my } \\
\text { English skills }\end{array}$ & 5 & 10 \\
\hline $\begin{array}{l}\text { I read } \\
\text { English for } \\
\text { improving } \\
\text { my } \\
\text { knowledge. }\end{array}$ & 5 & 10 \\
\hline $\begin{array}{l}\text { I read } \\
\text { English for } \\
\text { doing } \\
\text { assignments. }\end{array}$ & 25 & 50 \\
\hline $\begin{array}{l}\text { I read } \\
\text { English for } \\
\text { entertainmen } \\
\text { ts. }\end{array}$ & 10 & 20 \\
\hline $\begin{array}{l}\text { I read } \\
\text { English } \\
\text { because my } \\
\text { parent } \\
\text { support me }\end{array}$ & 5 & 10 \\
\hline
\end{tabular}

Based on table 4, the most common of students' activity were read English for doing assignments that consists of 25 respondents' (50\%). It was followed students' read English for entertainments that consists of 10 respondents $(20 \%)$. Then, almost same of the students' read English to improve my English skills that consist of 5 respondents $(10 \%)$, the students' read English for improving my knowledge that consists of 5 respondents 
(10\%) and the students' read English because give support that consists of 5 respondents $(10 \%)$.

The most of students' activity were read English for doing assignments that caused many the other lesson have the home project. So, the students' orientation just the assignments have done. The other, students' read English for entertainments because almost of them read of comic and pictures' story.

The related studies, students' orientation is also conveying they underestimate of English. This data give information the mental blocking of student in study English.

Table. 5 Underestimate about English for Students

\begin{tabular}{lcc}
\hline $\begin{array}{c}\text { The } \\
\text { Students, } \\
\text { Activity }\end{array}$ & $\begin{array}{c}\text { Amount of } \\
\text { Responden } \\
\text { ts }\end{array}$ & $\begin{array}{c}\text { Percenta } \\
\text { ge }(\%)\end{array}$ \\
\hline $\begin{array}{l}\text { English is not } \\
\text { guaranteed } \\
\text { support my } \\
\text { carrier in } \\
\text { future }\end{array}$ & 15 & 30 \\
$\begin{array}{l}\text { English is not } \\
\text { priority }\end{array}$ & 15 & 30 \\
because it \\
doesn't use \\
for daily \\
communicati \\
on
\end{tabular}

\begin{tabular}{l} 
Competence \\
I feel English \\
just for study \\
at school and \\
doing \\
assignment \\
$\begin{array}{l}\text { I don't have } \\
\text { motivation } \\
\text { because }\end{array}$ \\
$\begin{array}{l}\text { English is } \\
\text { difficult. }\end{array}$ \\
\hline
\end{tabular}

Based on table 5, the most common have same data of students' underestimate were English is not guaranteed support my carrier in future that consists of 15 respondents' (30\%) and the students' underestimate were English is not priority because it doesn't use for daily communication that consists of 15 respondents' $(30 \%)$. It was followed students' underestimate were they feel English just for study at school and doing assignment that consists of 10 respondents $(20 \%)$. Then, almost same of the students' underestimate were they don't have interest and talent in English Competence that consists of 5 respondents' $(10 \%)$ and they don't have motivation because English is difficult that consists of 5 respondents' $(10 \%)$.

The most students' underestimate were English is not guaranteed support my carrier in future because they unknown about their orientation about working in English program. It still less information how get carrier in English competence. The most students' underestimate were English is not 
priority because it doesn't use for daily communication which they able to work without communicated English competence. So, the student's intention were only improving carrier in local target.

\section{CONCLUSION}

Based on the result of the research that found the students' MTS Al-hidayah Tapung Hilir Sub-disrict Kampar Regency which the little students like reading English that consists of 15 respondents $(30 \%)$. It has indication caused by less of motivation to reading especially in English text. Then, reading habit is not became our culture in young generation which this indicator the most common of student's seldom reading English book that consists of 30 respondents' $(60 \%)$. The otherside, the most common of students' activity were doing in free time watching TV that consists of 25 respondents' (50\%). It mean, the students' waste the time for un-useful activity how the students' improving their knowledge but they are less reading. Then, the time for reading English the most common of students' activity were read for doing assignments that consists of 25 respondents' (50\%). It mean, if the students don't have home assignment the will not study. The others factor about learning subject to much in a day, they are fed 6-7 different lessons that is very tiring. So, they have to divide time to doing each subject which rottenly rise-up boring and stress. The last factor about students' underestimates, the most common have same data of students' underestimate were English is not guaranteed support my carrier in future that consists of 15 respondents' (30\%) and the students' underestimate were English is not priority because it doesn't use for daily communication that consists of 15 respondents' (30\%). It means them less orientation and believes to improving their skill in English.

Based on data above, it needs the culture of reading habit especially in English by promoting English club. The teacher and the parent collaboration to supporting awareness of reading habit become a duty. Reading habit is essential because it became determine of human development Index in our country.

\section{REFERENCES}

Bashir and Mattoo (2012) citied in Micheal Owusu-Ache, \& Aw. (2014). Reading Habits Among Students and its Effect on Academic P erformance: A S tudy of $\mathrm{S}$ tudents of Koforidua $\mathrm{P}$ olytechnic. Univ Ersit $\mathrm{Y}$ of $\mathrm{N}$ Ebraska - L in Coln Di gitalC Omm ons@U Niv Ersit Y of N Ebraska L in Coln Library Philosophy and Practice (E-Journal).

Chettri, M. K., \& Rout, D. S. K. (n.d.). Reading Habits - An Overview. https://doi.org/2279 - 0837

Creswell, J. W. (2015). Educational Research: Planning, Conducting, 
and Evaluating Quantitative and Qualitative Research.

Erna Iftanti. (2012). A S Urvey of The English Reading Habits of EFL Students In Indonesia. Education, pages :23 (students' reading habits). Retrieved from http://teflin.org/journal/index.php/jo urnal/article/viewFile/144/136

Kasriyati, Destina. "A Study on Students' Ability in Identifying Types of Supporting Ideas in The Texts." ELT-Lectura 3.1 (2016).

Muktiono, J. D. (2013). Aku cinta buku: menumbuhkan minat baca pada anak

UNDP in Indonesia. (2014). United Nations Development Programme. https://doi.org/0969-450
Syaveny, N. (2017). Teaching Reading Comprehension by Using Directed Activities Related To Text (DRTA) For the Students. Education, 1. Retrieved from https://www.researchgate.net/public ation/320574985_Teaching_Readin g_Comprehension_By_Using_Dire cted_Activities_Related_To_Text_ Drta_For_The_Students

Verplanken and Orbell (2003). (2016). A new measure of reading habit: Going beyond behavioral frequency. Frontiers in Psychology, https://doi.org/http://dx.doi.org/10.3 389/fpsyg.2016.01364

Wong, J. (2013). 8 Reasons Why Reading is So Important, 3. Retrieved from http://www.inspirationboost.com/8reasons-why-reading-is-soimportant. 